Arch. Dis. Childh., 1963, 38, 220.

FRUCTOSAEMIA

\title{
AN INBORN ERROR OF FRUCTOSE METABOLISM
}

\author{
BY \\ B. LEVIN, V. G. OBERHOLZER, G. J. A. I. SNODGRASS, L. STIMMLER \\ and MARY J. WILMERS \\ From Queen Elizabeth Hospital for Children, London
}

(RECEIVED FOR PUBLICATION NOVEMBER 20, 1962)

Although essential fructosuria has been known for 70 years and has been recognized as an inborn error of metabolism for more than 20 years (Lasker, 1941 ), it is only recently that a second metabolic anomaly involving fructose has been described by Froesch, Prader, Labhart, Stuber and Wolf (1957). These authors recorded four affected (two children and two adults) and three probably affected members of a large family in which intermarriage had been frequent. This condition of fructose intolerance, although similar in some respects to essential fructosuria, differed in that ingestion of fructose or fructose-containing foods caused a sharp and prolonged fall in the blood glucose level accompanied by the clinical symptoms of severe hypoglycaemia. The continued ingestion of fructose in infancy could result in retarded growth and mental development.

Subsequently, Froesch, Prader, Wolf and Labhart (1959) suggested that, in essential fructosuria, the metabolic anomaly lay in a deficiency of the hepatic fructokinase (Fig. 1) which converts the fructose to fructose-1-phosphate, whereas in fructose intolerance there was an absence or deficiency of fructose-1phosphate aldolase, cleaving fructose-1-phosphate to glyceraldehyde and dihydroxyacetone phosphate (Fig. 1). This hypothesis was based mainly on the prolonged fall in serum phosphate which occurred on fructose administration, indicating that the conversion of fructose to fructose-1-phosphate by the specific fructokinase had proceeded normally, with accumulation of the phosphate in the cell.

The clear recognition of this syndrome has been rapidly followed by several further reports of cases (Wolf, Zschocke, Wedemeyer and Hübner, 1959; Dormandy and Porter, 1961; Dubois, Loeb, Ooms, Gillet, Bartman and Champenois, 1961; Jeune, Planson, Cotte, Bonnefoy, Nivelon and Skosowsky, 1961; Nikkilä, Somersalo, Pitkänen and Perheen- tupa, 1962). In four instances, one other member of the family was affected by the same metabolic abnormality but less severely.

We now record three further examples of this condition, two sibs of one family and the third in an unrelated family. The younger of the two sibs was admitted to hospital at 7 weeks of age because of reluctance to take feeds, lethargy and severe weight loss. The presence of fructose in the urine on many occasions, so long as the patient was on feeds containing sucrose, led to the diagnosis. Examination of the rest of the family revealed another affected child, normal in intelligence and growth.

The investigations described in this article afford further evidence for the suggested underlying metabolic anomaly in this condition and also show the clinical and biochemical similarity between it and galactosaemia, for which reason we prefer to call it fructosaemia, rather than fructose intolerance. As these cases were discovered within a period of a few months of each other, it is likely that the condition is more common than was at first thought and because it may lead to mental and physical retardation and underdevelopment, it is important that it should be recognized as early as possible, since it is easily treated.

\section{Case Reports}

Case 1. A girl was born at home on July 3, 1961, after a normal pregnancy and delivery, birth weight $9 \mathrm{lb} .8 \mathrm{oz}$. $(4 \cdot 3 \mathrm{~kg}$.). The parents are not consanguineous and this is the fourth child. She was breast-fed for 13 days and then changed to cows' milk and water. On the fourteenth day she vomited after her 8 p.m. feed and became blue over her entire scalp. She was admitted the next day to King's College Hospital for investigation of cyanosis and purpura of the scalp. During her twoday stay in hospital, the cyanosis disappeared and the purpura improved. She was discharged on a diet of 


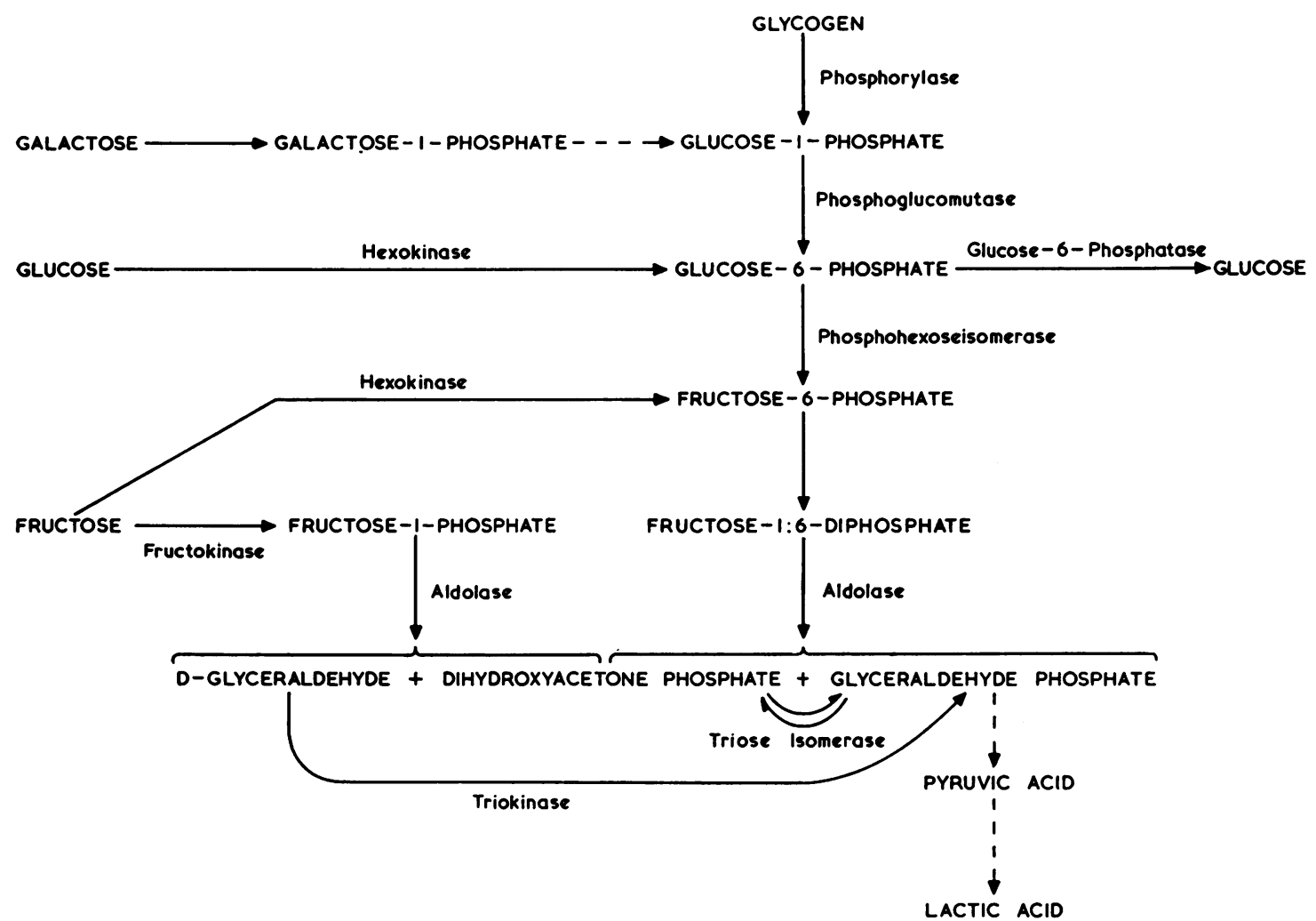

Fig. 1.-Relevant pathways of fructose metabolism. Broken arrows indicate that intermediate stages have been omitted.

full-cream dried milk with added cane sugar and this feed was continued at home.

On August 21, 1961, she was readmitted to hospital because of reluctance to feed, lethargy and loss of weight. The infant then weighed $7 \mathrm{lb} .12 \mathrm{oz}$. $(3.5 \mathrm{~kg}$.), the abdomen was distended and the liver slightly enlarged. When, two days later, the serum electrolyte levels revealed a metabolic acidosis, she was given, in addition to her normal feeds, one-sixth molar lactate solution over the next 48 hours. Her condition changed little until, on the eighth day after admission, she collapsed into semi-consciousness with grunting respirations. The true blood glucose was found to be $37 \mathrm{mg}$. per $100 \mathrm{ml}$. She improved after an intravenous injection of $50 \%$ dextrose but had further convulsions on each of the succeeding two days, responding on each occasion to intravenous glucose, although paraldehyde was also given intramuscularly.

When she was admitted on September 1, 1961, to the Queen Elizabeth Hospital for Children, her condition was essentially unchanged, except that oedema had developed. Her abdomen was distended, the liver was enlarged and ascites was present. She was fed on a full-cream dried milk mixture with added cane sugar. The day after admission a convulsion occurred, for which she was given paraldehyde. She had a persistent metabolic acidosis which was treated with alkali therapy. Examination of the urine showed the presence of fructose on a number of occasions during the next few weeks and paper chromatography revealed a severe aminoaciduria. A random blood sample showed a raised level of fructose (14 mg. per $100 \mathrm{ml}$.).

One month after admission she contracted severe gastro-enteritis due to Esch. coli 0119, for which she was given intravenous therapy with a glucose-electrolyte mixture. Later, when oral feeding was restored, the dried milk mixture with added cane sugar was replaced by S.M.A. alone. She made a gradual recovery. Her underlying condition, however, was unchanged. After about a fortnight, because she was difficult to feed, the dried milk mixture with added sucrose was restored, but again with no improvement. A second estimation of the blood fructose gave a level of $24 \mathrm{mg}$. per $100 \mathrm{ml}$. Fructose intolerance, therefore, was suspected. From October 23, all cane sugar was excluded from the diet. During the next week her condition altered little, but thereafter she improved rapidly, although for the first time the spleen was noted to be enlarged to one finger's breadth. Within a fortnight, the oedema and ascites disappeared, she took her feeds 


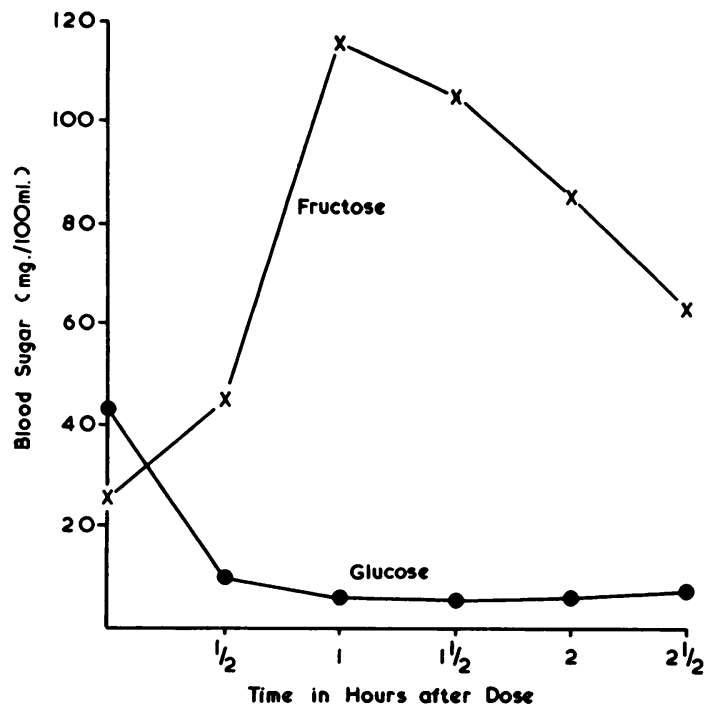

Fig. 2.-Case 1. Changes in the levels of blood fructose and glucose following ingestion of $8 \mathrm{~g}$. fructose $(2 \cdot 2 \mathrm{~g} . / \mathrm{kg}$.).

well and became more alert. A fructose tolerance test was carried out on November 14 (Fig. 2) and confirmed the diagnosis. One hour after fructose administration she became very drowsy and had a convulsion. She responded immediately to $5 \%$ glucose solution given intravenously.

She was discharged at the age of $5 \frac{1}{2}$ months, a well infant although she only weighed $9 \frac{1}{2} \mathrm{lb} .(4 \cdot 3 \mathrm{~kg}$.) and the liver was still enlarged. Her progress since then has been uneventful and her weight gain has been rapid, $19 \mathrm{lb} .10 \frac{1}{2} \mathrm{oz}$. $(8 \cdot 9 \mathrm{~kg}$.) at 1 year, but the liver enlargement remains.

Case 2. A girl, a sib of Case 1, was born at home on January 20, 1955, after a normal pregnancy and delivery; birth weight $9 \mathrm{lb} .12 \mathrm{oz}$. (4.4 kg.). She was breast-fed until 8 months of age, bottle feeding having been unsuccessfully attempted at 4 months. Semisolid, and later solid, foods were given from 6 months. When weaning was established, it was noted that savoury foods, e.g. Bovril, were more acceptable than other foods. She was seen at hospital at 10 months of age because of failure to thrive in the previous two months and it was then recorded that the infant refused all milk feeds, orange juice or anything sweet. She was a wasted baby, weight $13 \mathrm{lb} .13 \mathrm{oz} .(6 \cdot 3 \mathrm{~kg}$.). No special treatment was given, but she gained weight well thereafter. She was seen at $11 \frac{1}{2}$ months when she weighed $16 \mathrm{lb} .1 \mathrm{oz}$. $(7 \cdot 3 \mathrm{~kg}$.$) , and again at 15$ months when the recorded weight was $21 \mathrm{lb} .7 \mathrm{oz}$. $(9 \cdot 7 \mathrm{~kg}$.). She was thought then to be a little backward; she was beginning to sit up by herself and crawl. She walked at 2 years.

She is now $7 \frac{1}{2}$ years old, and of normal physical development. She attends primary school and has reached the average educational standard. Her mother considers her to be slower than her elder sister. She has always refused sweets, chocolates, ice-cream, fruits and carrots. Her I.Q. is 100 (Termann-Marrill).

Case 3. A girl was born in Bushey Maternity Hospital on March 17, 1962, birth weight $7 \mathrm{lb}$. $1 \mathrm{oz}$. $(3 \cdot 2 \mathrm{~kg}$.), after a pregnancy complicated by toxaemia. From the first, reconstituted evaporated milk feeds supplemented breast-feeding which ceased completely by the eighth day. From the fourteenth day the baby was fed on a diet of half-cream dried milk with added cane sugar. She was admitted to the Queen Elizabeth Hospital for Children at 17 days of age because of lethargy, failure to thrive and with projectile vomiting after feeds for the previous four days. The provisional diagnosis was pyloric stenosis. Although there was some visible peristalsis, no tumour could be felt. She then weighed $6 \mathrm{lb} .9 \frac{1}{2}$ oz. $\left(2.9 \mathrm{~kg}\right.$.), i.e. $7 \frac{1}{2} \mathrm{oz} .(0 \cdot 2 \mathrm{~kg}$. $)$ below her birth weight. The liver was only slightly enlarged. She was given the usual feeds of half-cream National dried milk mixture with added cane sugar. Vomiting persisted, she lost weight and the liver became larger. Plasma electrolyte levels on admission showed a moderate acidosis and examination of the urine detected a reducing substance which was found on paper chromatography to be mainly fructose with small amounts of glucose and traces of lactose and sucrose. Gross aminoaciduria was also present. A fasting blood glucose taken eight days after admission showed a marked hypoglycaemia $(3 \mathrm{mg}$. per $100 \mathrm{ml}$.) and the fructose levels taken about one hour after an ordinary feed with added cane sugar were high. Ten days after admission, therefore, all fructose-containing foods were rigorously excluded from the diet. Although there had been a slight gain in weight $\left(3 \frac{1}{2} \mathrm{oz} .(0 \cdot 1 \mathrm{~kg}).\right)$ in the first 10 days, thereafter, weight gain was greatly improved. Now (aged 4 months) she weighs $11 \mathrm{lb} .8 \mathrm{oz}$. $(5 \cdot 2 \mathrm{~kg}$.) which is well under her expected weight (Levin, Mackay, Neill, Oberholzer and Whitehead, 1959), but is otherwise a normal infant. The liver is just palpable. A liver biopsy was taken on July 17 for enzyme studies. Progress since then has been uneventful.

Family History. In the first two cases there was no history of fits, mental defect or other relevant disease in the parents grandparents or other relatives. In the third case, only the mother was available for examination and, in her case also, there was no relevant family history.

\section{LABORATORY INVESTIGATIONS}

The estimations of the level of plasma and urinary constituents, including amino acids, phosphorus and magnesium, and of total blood sugar, glucose and fructose, were performed according to the standard micromethods in use in this laboratory.

The serum and liver aldolase levels were determined by a modification of the method of Sibley and Lehninger (1949) and liver fructokinase by a modification of the method of Hers and Joassin (1961). Details of the enzyme methods will be published at a later date. 
TABLE 1

PLASMA TRANSAMINASE LEVELS (units)

\begin{tabular}{|c|c|c|c|c|c|c|c|}
\hline \multicolumn{3}{|c|}{ Effect of Sucrose in Diet } & \multicolumn{5}{|c|}{ Effect of Single Dose of Fructose ( $8 \mathrm{~g})}$. \\
\hline Case 1 & Before & $\begin{array}{l}\text { After } 3 \text { Weeks on } \\
\text { Sucrose-free Diet }\end{array}$ & & & 2 Days Later & 3 Days Later & 6 Days Later \\
\hline $\begin{array}{l}\text { SGPT } \\
\text { SGOT }\end{array}$ & $\begin{array}{l}756 \\
750\end{array}$ & $\begin{array}{l}165 \\
270\end{array}$ & & & $\begin{array}{l}430 \\
490\end{array}$ & $\begin{array}{l}239 \\
291\end{array}$ & $\begin{array}{l}120 \\
168\end{array}$ \\
\hline Case 3 & Before & $\begin{array}{l}\text { After } 6 \text { Weeks on } \\
\text { Sucrose-free Diet }\end{array}$ & Fasting Level & $\begin{array}{l}1 \frac{1}{2} \text { Hours After } \\
\text { Fructose }\end{array}$ & & & \\
\hline $\begin{array}{l}\text { SGPT } \\
\text { SGOT }\end{array}$ & $\begin{array}{l}740 \\
223\end{array}$ & $\begin{array}{r}96 \\
129\end{array}$ & $\begin{array}{l}50 \\
85\end{array}$ & $\begin{array}{l}520 \\
485\end{array}$ & & & \\
\hline
\end{tabular}

\section{Biochemical Investigations and Liver Function Tests}

Case 1. Apart from a low carbon dioxide combining capacity and raised plasma chloride, the electrolytes were within normal limits. On admission the serum protein was low, presumably accounting for the low plasma calcium found. Plasma phosphorus was usually low, and on one occasion when she was severely ill it was less than $1.0 \mathrm{mg}$. per $100 \mathrm{ml}$. The significance of this finding is discussed below. The alkaline phosphatase initially was within normal limits, but later the level rose to $58 \mathrm{~K}$.A. units per $100 \mathrm{ml}$., probably indicating a moderately severe impairment of liver function. After sucrose had been excluded from the feeds, the levels returned to normal values within a few weeks.

In the early stages only the serum glutamic-oxaloacetic transaminase (SGOT) was above the normal level. Later, when she was more severely ill, both the serum glutamic-pyruvic transaminase (SGPT) and SGOT were increased, afterwards falling to the initial levels. Two days after a test dose of fructose was administered, the levels again rose, returning to the earlier levels a week after the fructose tolerance test (see Table 1).

Urinary and Serum Amino Acids. Paper chromatography of the urine, performed on a number of occasions when the patient was between 2 and 4 months of age, showed a generalized increase in the excretion of the amino acids. The proportion of urinary amino acid nitrogen to total urinary nitrogen fluctuated between $3.7 \%$ and $17 \cdot 3 \%$, compared with a normal level of up to $3 \%$ for an infant of this age. The amino acid excretion fell to less than $3 \%$ within a fortnight of the exclusion of sucrose from the feeds. On the day after the fructose tolerance test, the proportion of amino acid nitrogen to total nitrogen rose to nearly $5 \%$, dropping to half this value two days later.

The serum amino-nitrogen levels determined on three occasions were $8.3 \mathrm{mg}$., $4.7 \mathrm{mg}$. and $3.5 \mathrm{mg}$. per $100 \mathrm{ml}$., the first value coinciding with the greatest aminoaciduria found. The observation of a high amino acid nitrogen level in the plasma suggests that this could be classified as an overflow aminoaciduria (Dent, 1957) such as would occur in severe hepatic disease, but it does not apply to those times when the level of amino acids in the serum was within normal limits. Cusworth, Dent and Flynn (1955) claim that in galactosaemia the hyperamino- aciduria is of renal type, but Van Geffel, Devriendt Dustin, Vis and Loeb (1959) found high plasma amino acid levels associated with hyperaminoaciduria in a case of galactosaemia with marked hepatic disturbance and concluded that a hepatic, as well as a renal factor was, involved. Our findings suggest that a similar combination of factors is involved in fructosaemia.

Magnesium. The serum magnesium levels were estimated on a number of occasions before the first fructose tolerance test. The levels ranged between 1.0 and $1.8 \mathrm{mg}$. per $100 \mathrm{ml}$. $(0.83$ to $1.08 \mathrm{mEq} /$ litre $)$; the significance of these low levels and the alterations during the tolerance tests is discussed below.

Case 3. The plasma electrolytes were within normal limits except for the carbon dioxide capacity which showed a moderate diminution. Initially the serum transaminases were moderately elevated. Six weeks after a fructose-free diet had been instituted, the transaminases had returned to normal levels, despite two fructose tolerance tests carried out in the intervening period (Table 1). Other liver function tests were normal.

As in Case 1, the urinary amino acids were initially greatly increased (amino acid nitrogen $21 \cdot 3 \%$ of the total nitrogen), but five weeks after the commencement of treatment the urinary amino acid excretion fell to normal values (amino acid nitrogen $1 \%$ of the total urinary nitrogen).

\section{Carbohydrate Metabolism}

Case 1. Paper chromatography usually revealed the presence of fructose during the period before treatment and, on one or two occasions, traces of glucose and galactose.

Glucose Tolerance Test. This was performed about three weeks after fructose-containing foods had been eliminated from the feeds and was found to be normal. The glycogen stores were judged to be normal on the bases of the glucagon test, a rise of $16 \mathrm{mg}$. per $100 \mathrm{ml}$. in the blood glucose being noted 30 minutes after injection of $100 \mu \mathrm{g}$. glucagon.

Fructose Tolerance Test. The results of the administration of fructose $(8 \mathrm{~g}$.) are shown in Fig. 2. The maximum blood fructose level attained was $116 \mathrm{mg}$. per $100 \mathrm{ml}$. one hour after fructose was given, and the level 
was still very high two and a half hours later. The fall in the true blood glucose was immediate and severe, dropping to $10 \mathrm{mg}$. per $100 \mathrm{ml}$. at the end of 30 minutes, and falling still lower thereafter. Even when the blood fructose level was receding, the blood glucose failed to rise from its extremely low level.

Because it was possible that the low plasma phosphorus and magnesium levels were due to the metabolic anomaly, a second fructose tolerance test was performed after the infant had been on a fructose-free diet for 12 weeks. A smaller loading dose of fructose $(2 \cdot 5 \mathrm{~g}$.) was used in order to avoid too severe a hypoglycaemic effect, and the results are shown in Fig. 3. The fall in blood glucose was even greater, despite the smaller dose, although the rise in blood fructose was relatively slight. The total blood sugar, as determined by the Folin-Wu method, masked the fall in blood glucose so that the hypoglycaemia would have been overlooked if the usual method of estimation of blood sugar had been used. There was also a significant fall in the plasma phosphorus, from an initial level of $4.5 \mathrm{mg}$. to $2.4 \mathrm{mg}$. per $100 \mathrm{ml}$. one hour after the fructose was given, rising again to $3.3 \mathrm{mg}$. per $100 \mathrm{ml}$. at the end of two and a half hours. This fall was accompanied by a rise in the serum magnesium level from $2.2 \mathrm{mg}$. to a maximum of $3.1 \mathrm{mg}$. at one and a half hours, falling to $2.6 \mathrm{mg}$. per $100 \mathrm{ml}$. at the end of the test. Hypoglycaemic symptoms were apparent 30 minutes after fructose administration and a convulsion occurred towards the end of the test, responding rapidly to intravenous glucose.

A similar investigation was performed on both parents and the three sibs of Case 1 . The result obtained with Case 2, the affected sib, is shown in Fig. 4. Oral glucose had to be given to avert a hypoglycaemic attack one hour after the fructose had been given. The rise in blood fructose was more marked and so was the fall in blood glucose. The serum phosphorus fell from an initial fasting level of $4.4 \mathrm{mg}$. to $3.0 \mathrm{mg}$. at 45 minutes, before rising to $3.9 \mathrm{mg}$. per $100 \mathrm{ml}$. at one and threequarter hours. The serum magnesium rose from an initial level of $1.65 \mathrm{mg}$. to $2.5 \mathrm{mg}$. per $100 \mathrm{ml}$. at the end of 30 minutes and fell only slightly thereafter.

The results for the rest of the family were quite normal. As an example, the results from a sib aged 3 years are shown in Fig. 5. The blood fructose levels did not rise by more than $20 \mathrm{mg}$. per $100 \mathrm{ml}$. at the maximum, and in each case there was a rise, not a fall, in the blood glucose and plasma phosphorus. It is also important to note that there appeared to be no significant change in the level of magnesium during the tesi.

Galactose Tolerance Test. This gave a rise in blood galactose levels well within normal limits, while the true blood glucose also rose after administration of the galactose, in contrast to the findings during the fructose tolerance test.

Sorbose Tolerance Test. In view of the close chemical similarity of sorbose and fructose, it was thought worth while to observe the effect of administration of sorbose. There was a sustained increase in blood sorbose, over
$60 \mathrm{mg}$. per $100 \mathrm{ml}$. at the maximum, which occurred at least three and a half hours after the initial dose. This suggests some impairment in the ability to metabolize sorbose; however, the true blood glucose rose instead of falling, as happened with fructose.

Case 3. Paper chromatography of the urine, before treatment was instituted, again usually revealed only fructose, but on two occasions a fasting specimen of urine showed, in addition to fructose, a small amount of glucose and traces of sucrose and lactose.

Injection of glucagon $(100 \mu \mathrm{g}$.) gave a normal blood glucose response.

Fructose Tolerance Tests. The result of a loading dose of $6 \mathrm{~g}$. fructose (Fig. 6) was similar in all respects to that in Cases 1 and 2 . The rise in plasma magnesium was again very significant, from $2 \cdot 1$ to $2 \cdot 6 \mathrm{mg}$. per $100 \mathrm{ml}$., the highest level being attained two hours after the fructose had been given.

Galactose Tolerance Test. This was within normal limits.

Sorbose Tolerance Test. The result of this test was very similar to that of Case 1 with a rise of over $60 \mathrm{mg}$. in the blood sorbose level, still sustained at the end of two hours.

\section{Enzyme Studies}

Serum Aldolase. These levels, using both fructose-1phosphate and fructose-1:6-diphosphate as substrates, were measured in some cases of infective hepatitis and in Case 1 during the illness and after recovery, as well as in some normals. With fructose-1:6-diphosphate as substrate, the normal levels found were usually between 5 and 7 units, one unit being 1 umole of substrate utilized per minute per litre of serum. Very much higher levels, up to 50 units, were obtained during hepatitis, and these fell as the liver dysfunction receded to the values obtained in normal sera. A similar high level was found in Cases 1 and 3 during the height of the liver dysfunction, 30 and 20 units respectively, compared with their normal values of 6 units.

The low levels of fructose-1-phosphate activity found in normal sera could only be approximately determined by the micromethod used, and were often zero, and usually less than 1.5 units. During hepatitis, high levels were found, up to 40 units, falling as the hepatitis receded. In Cases 1 and 3 the loiv levels found (less than 1 unit) remained unchanged despite the liver impairment.

Liver Enzymes. The fructokinase and aldolase activities towards both fructose-1-phosphate and fructose$1: 6$-diphosphate were estimated in a biopsy specimen of liver within one hour of removal and compared with a fresh specimen similarly obtained from a case of liver dysfunction (Y.G.). The aldolase levels in two normal infants and two suffering from a condition unlikely to affect carbohydrate metabolism are also included in 


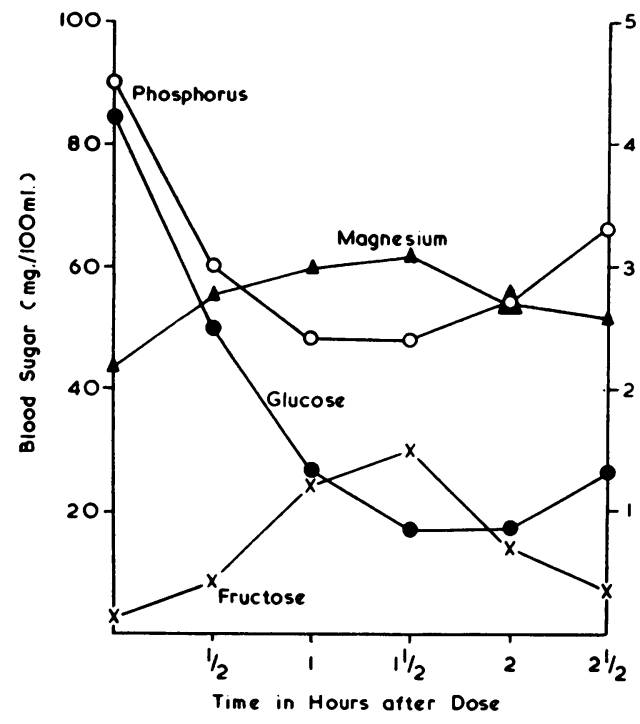

FIG. 3.-Case 1. Changes in the levels of blood fructose and glucose and plasma phosphorus and magnesium following ingestion of $2.5 \mathrm{~g}$. fructose $(0.5 \mathrm{~g} . / \mathrm{kg}$.$) .$

Table 3. These latter results are considerably lower than normal liver, since they were not determined on fresh specimens, but they are shown because biopsy specimens of liver were only rarely obtained, and also because the ratio of the aldolase activities appears to be unaffected.

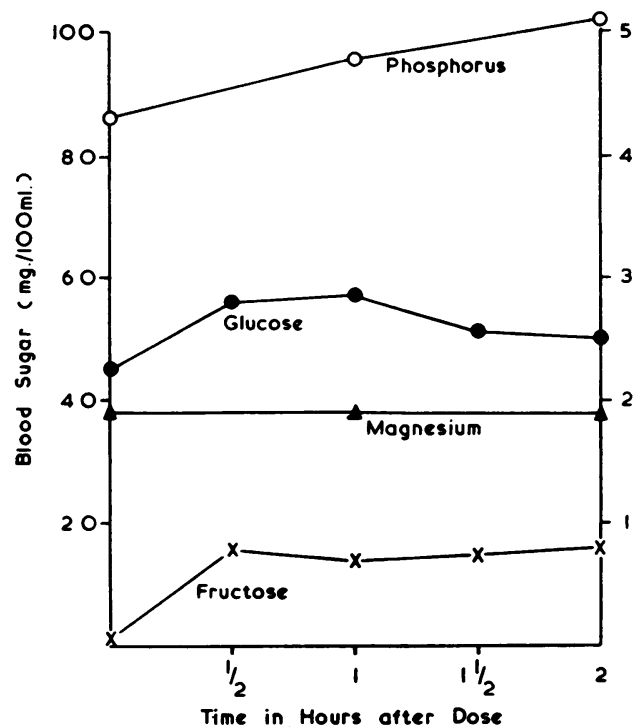

FIG. 5.-Normal sib of Cases 1 and 2. Changes in the levels of blood fructose and glucose and plasma phosphorus and magnesium following ingestion of $22 \mathrm{~g}$. fructose $(1 \cdot 5 \mathrm{~g} . / \mathrm{kg}$.).

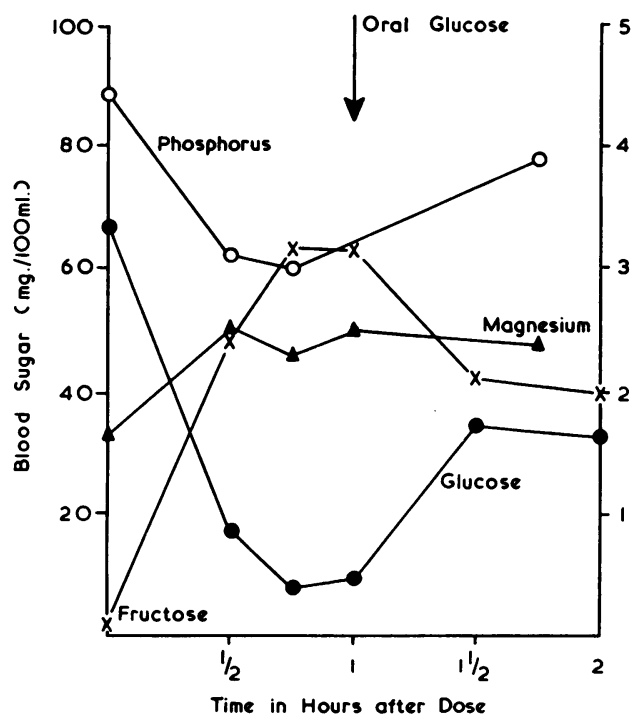

Fig. 4.-Case 2. Changes in the levels of blood fructose and glucose and plasma phosphorus and magnesium following ingestion of $30 \mathrm{~g}$. fructose $(1 \cdot 2 \mathrm{~g} . / \mathrm{kg}$.). Oral glucose was given at the end of one hour.

\section{Discussion}

Fructosaemia shows a marked resemblance, clinically and biochemically, to galactosaemia. In both, there are diverse effects resulting in hepatic, renal and cerebral dysfunction. Table 2 summarizes

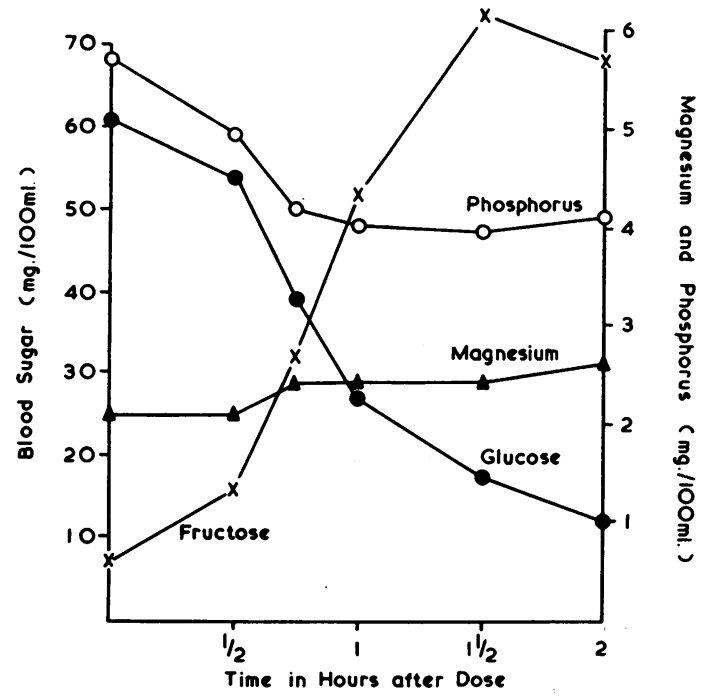

Fig. 6-Case 3. Changes in the levels of blood fructose and glucose and plasma phosphorus and magnesium following ingestion of $2.5 \mathrm{~g}$. fructose $(0.6 \mathrm{~g} . / \mathrm{kg}$.). 
TABLE 2

\begin{tabular}{|c|c|c|}
\hline \multicolumn{2}{|c|}{ Clinical Manifestations in 16 cases } & Laboratory Findings \\
\hline Early & Late & \multirow[b]{2}{*}{ 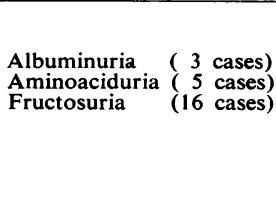 } \\
\hline $\begin{array}{ll}\text { Vomiting } & (9 \text { cases }) \\
\text { Anorexia } & (7 \text { cases }) \\
\text { Jaundice } & \text { ( } 3 \text { cases }) \\
\text { Retardation of growth } & (5 \text { cases }) \\
\text { Hepatomegaly } & \text { ( } 8 \text { cases }) \\
\text { Splenomegaly } & (4 \text { cases }) \\
\text { Hypoglycaemic symptoms } & (13 \text { cases })\end{array}$ & $\begin{array}{l}\text { Slight mental retardation (4 cases) } \\
\text { Convulsions } \\
\text { Distaste for sweet foods ( } 5 \text { cases) }\end{array}$ & \\
\hline
\end{tabular}

TABLE 3

ENZYME LEVELS IN LIVER

\begin{tabular}{|c|c|c|c|c|c|}
\hline \multirow{2}{*}{\multicolumn{2}{|c|}{ Case }} & \multicolumn{4}{|c|}{ Enzyme (units) } \\
\hline & & \multirow[t]{2}{*}{ Fructokinase } & \multicolumn{3}{|c|}{ Aldolase } \\
\hline & & & Fructose-1-Phosphate & Fructose-1 :6-Diphosphate & Ratio of FDP/F1P \\
\hline $\begin{array}{l}\text { Normal } \\
\text { Normal } \\
\text { Hyperammonaemia } \\
\text { Hyperammonaemia } \\
\text { Y.G. } \\
\text { Case } 3\end{array}$ & $\begin{array}{l}\text { (necropsy)* } \\
\text { (biopsy) }{ }^{*} \\
\text { (necropsy)* } \\
\text { (biopsy)* } \\
\text { (biopsy) } \\
\text { (biopsy) }\end{array}$ & $\begin{array}{l}- \\
\bar{Z} \\
0 \cdot 31 \\
0 \cdot 34 \\
0 \cdot 33\end{array}$ & $\begin{array}{r}2 \cdot 8 \\
4 \cdot 9 \\
5 \cdot 2 \\
5 \cdot 6 \\
15 \cdot 1 \\
0 \cdot 1\end{array}$ & $\begin{array}{r}4 \cdot 4 \\
7 \cdot 3 \\
8 \cdot 8 \\
7 \cdot 2 \\
21 \cdot 8 \\
3 \cdot 4\end{array}$ & $\begin{array}{l}1 \cdot 57 \\
1 \cdot 49 \\
1 \cdot 69 \\
1 \cdot 29 \\
1 \cdot 44 \\
30 \text { (approx.) }\end{array}$ \\
\hline
\end{tabular}

1 unit $=1 \mu \mathrm{mol}$. of substrate utilized per $\mathrm{g}$. liver per minute.

* Estimation performed on liver kept for three days at $-22^{\circ} \mathrm{C}$.

+ Estimation performed on liver kept for three days at $4^{\circ} \mathrm{C}$.

$\ddagger$ Estimation performed on liver within one hour of removal.

the main features of the condition from the 16 cases, five males and 11 females, recorded, including the three cases now described, although in some the clinical information is incomplete. Apart from the different hexoses involved, the findings are almost identical with those of galactosaemia with the exception that no cases of cataract have been described in fructosaemia.

The mode of presentation depends on the agegroup. The younger group, usually less than 6 months of age, presents as failure to thrive. The older cases are more usually discovered among the relatives of an affected infant. They are often symptomless, but have a marked aversion to sweet foods, as had our second case. The main factor determining the age at which symptoms appear is the time at which breast-feeding is discontinued. If this ceases early, with a change to artificial milk feeds and added cane sugar, then almost at once there is anorexia, vomiting, lethargy, hypotonia and failure to gain weight. If breast-feeding is maintained until solids are introduced, the infant is usually over 6 months old and able to make a positive rejection of feeds which make him ill. Because of this, weaning from the breast is difficult until it is found that only non-sweet foods are acceptable. It seems likely that the strong aversion to sucrose or fructose-containing foods is a conditioned response, similar to that seen in aversion therapy. It is logical also to assume that the later in life the infant begins to ingest fructose-containing foods, the less severe will be the sequelae. Similarly, in a galactosaemic infant, if for any reason he has refused or been taken off breast or cows' milk, or has diminished milk feeds, the sequelae will be less severe.

Although fructosaemia cannot readily be differentiated from galactosaemia on clinical grounds alone, one feature in the history may point to the correct diagnosis. In fructosaemia, the infant becomes ill when taken off the breast, whereas in galactosaemia, symptoms occur as soon as breast or cows' milk feeding is begun.

The association of failure to thrive with vomiting and anorexia, hepatomegaly and hypoglycaemic attacks, following weaning from the breast, will suggest the diagnosis which is confirmed by the laboratory findings. The diagnosis of fructosaemia may be overlooked if it is not borne in mind that, in contrast to galactosaemia, only small amounts of the sugar involved are found in the urine. Further, a hypoglycaemia may not be detected in either syndrome if reliance is placed only upon a total blood sugar estimation. 


\section{Biochemical Investigations}

Metabolic Defect. Recent investigations (Leuthardt, 1957; Hers, 1957) have clarified the metabolic pathway of fructose in the body and its interrelation with glucose (Fig. 1). In the liver cell, fructose is phosphorylated in the presence of adenosine triphosphate (ATP) and magnesium ions by a specific fructokinase to fructose-1-phosphate, which then undergoes cleavage by an aldolase to a mixture of trioses which are intermediates in the metabolism of glucose. Fructose can also be converted by means of a non-specific hexokinase into fructose-6-phosphate, also a stage in the glycolytic pathway. This can only be of slight importance in the metabolism of fructose, however, owing to the greater affinity of the kinase for glucose, the presence of which in concentrations normally found will inhibit any activity towards fructose. The metabolic pathway for glucose includes the cleavage of fructose-1:6-diphosphate by aldolase to a mixture of trioses. Although Leuthardt, Testa and Wolf (1953) have claimed to demonstrate by chromatographic separation the existence of two specific aldolases acting on fructose-1-phosphate and fructose-1:6-diphosphate respectively, the balance of evidence is against this view. Thus, Peanasky and Lardy (1958) have shown that purified bovine liver aldolase could split both substrates, the affinity for the fructose diphosphate being twice as great as for fructose-1-phosphate. Tung, Ling, Byrne and Lardy (1954) have proved that aldolase from rabbit muscle could also split both substrates, although the activity towards the fructose diphosphate was, in this case, about six times greater than for fructose-1-phosphate. Finally, Hers and Joassin (1961) could not confirm the results of Leuthardt et al. (1953).

Although a demonstration of the absence or marked diminution of the activity of aldolase in the liver of an affected infant would have afforded the most convincing proof of the correctness of the suggestion of Froesch et al. (1959), this was not thought justified in Case 1 or Case 2. At first, it was believed that alterations in serum or erythrocyte aldolase might throw some light on the aetiology. Unfortunately, although the enzymatic activity of the aldolase in normal serum or erythrocytes towards fructose-1:6-diphosphate is appreciable, activity to fructose-1-phosphate is either very low or absent. The failure to find any of the latter enzymatic activity in the serum of Case 1, therefore, afforded no proof of the nature of the metabolic anomaly. Observations of patients with infective hepatitis, however, yielded some indirect evidence. Measurements of aldolase activity in the serum of such cases showed not only a marked rise in activity towards the fructose-1:6-diphosphate, but also the appearance of a high activity towards fructose-1-phosphate. The relative activities towards the two substrates become, at the height of the disease, very similar to the relative activities of liver aldolase. In Cases 1 and 3, during the period when the liver function tests, including the transaminases, showed a marked impairment and the rise in serum fructose1:6-diphosphate aldolase activity was similar to that found in infective hepatitis, there was no comparable rise in fructose-1-phosphate aldolase activity. Although this is a negative result, nevertheless it suggests strongly that the liver fructose-1phosphate aldolase activity was, in her case, deficient.

In Case 3 the correctness of the hypothesis of Froesch et al. (1959) was shown by a direct estimation of the liver aldolase activities. There was a difference, however, in the reduction of activities of the two substrates, that to fructose-1:6-diphosphate being reduced to about $16 \%$ of the value in a liver specimen in which the enzyme was also determined within one hour of removal, whereas that to fructose-1-phosphate was much more affected, being nearly zero (Table 3). Similar results were obtained by Hers and Joassin (1961) in two infants with the same condition, except that in the present case the liver aldolase activity to fructose-1-phosphate was reduced to an even lower level, with a ratio of activity to the two substrates of over 20, a value similar to that of muscle aldolase, whereas the ratio given by Hers and Joassin (1961) was only $6 \cdot 2$. In one of the cases of Nikkilä et al. (1962) the level of activity to fructose-1-phosphate was also zero, although their second case showed higher values. The finding of a normal level of fructokinase in the liver of the affected infant showed that the ability to convert fructose to fructose-1-phosphate was unimpaired.

Carbohydrate Metabolism. The striking fall in blood glucose which accompanies ingestion of fructose in these cases was first noted by Froesch et al. (1957) and is characteristic of all the cases described. It does not appear to be due to the high blood fructose level itself since in benign fructosuria there is only a relatively slight fall in blood glucose when fructose is given (Sachs, Sternfeld and Kraus, 1942). Dubois et al. (1961) have concluded, on the basis of the effect of oral fructose on the rate of utilization of glucose, that an increased insulin response is not the cause of the hypoglycaemia. This is also supported by the results of fructose ingestion on glucose levels in Case 1. Thus, on one occasion when a very small amount of fructose 
$(0.8 \mathrm{~g}$.) was given, the blood glucose dropped from a fasting level of $40 \mathrm{mg}$. to $31 \mathrm{mg}$. per $100 \mathrm{ml}$, whereas the fructose level had not yet risen above the fasting value of $2 \mathrm{mg}$. per $100 \mathrm{ml}$. It seems more likely that the formation of fructose-1-phosphate in the liver, as a result of the block, is responsible for the fall in blood glucose. The accumulation of fructose-1-phosphate itself could do this by an inhibition of one or more enzymes of the glycolytic pathway. Froesch et al. (1959) have shown that fructose-1-phosphate can inhibit the action of aldolase on fructose-diphosphate, and Sidbury $(1957,1959)$ has shown that excessive concentrations of galactose1-phosphate and fructose-1-phosphate can inhibit phosphoglucomutase (Fig. 1). On the other hand, Nikkilä et al. (1962) could find no inhibitory action of fructose-1-phosphate on phosphorylase, phosphoglucomutase or glucose-6-phosphatase (Fig. 1). Another explanation, not suggested previously, is that the fixation of available phosphate as fructose1-phosphate could hinder the conversion of glycogen to glucose, which requires the presence of reactive phosphate. In either case, the continued utilization of glucose by the peripheral tissues, together with the failure of mobilization of glycogen by the liver, could account for the observed immediate drop of blood glucose.

That sorbose fails to provoke a hypoglycaemic reaction (Wolf et al., 1959) is confirmed in our cases. Since the metabolic pathways of sorbose and fructose are identical so far as the formation of trioses, these authors have concluded that the enzymatic defect may be beyond this point. Since the anomaly is now proved to be a deficiency of aldolase, this explanation must be incorrect. It may be that the aldolase activity to sorbose-1-phosphate is not so impaired as it is to fructose-1-phosphate or that the sorbose-1-phosphate does not inhibit phosphoglucomutase and, therefore, there is no block in the conversion of glycogen to glucose.

Plasma Magnesium. The effect of fructose ingestion on the level of plasma magnesium has not been observed previously. Whilst the drop in plasma phosphorus can be explained by the normal conversion of fructose to fructose-1-phosphate, it is not so easy to account for the increase in plasma magnesium. It does not appear to be due to alterations in the blood level of glucose since an intravenous injection of glucose into a normal child, sufficient to raise the blood glucose from $85 \mathrm{mg}$. to $340 \mathrm{mg}$. per $100 \mathrm{ml}$. in 15 minutes, with a fall to the initial level in a further 30 minutes, failed to alter the plasma magnesium from a level of $2.0 \mathrm{mg}$. per $100 \mathrm{ml}$. by more than $0.1 \mathrm{mg}$. per $100 \mathrm{ml}$. and this actually was a fall rather than a rise, although the serum phosphorus fell from 4.2 to $3.8 \mathrm{mg}$. per $100 \mathrm{ml}$. over the same period. The rise in plasma magnesium is probably directly connected with the block in the cleavage of fructose-1-phosphate. The phosphorylation of fructose requires magnesium ions as well as ATP and Hers (1957) has shown that these two form a complex, ATP-Mg which reacts with the fructose to form adenosine diphosphate (ADP) and magnesium. In fructosaemia, owing to the enzymatic block, the reaction does not proceed further, so that an excess of magnesium could diffuse out of the liver cells into the interstitial fluid and into the plasma. The rise in plasma magnesium could result in renal loss, with a constant drain on magnesium so long as fructose is ingested, and this would finally lead to a low level of plasma magnesium, as was observed in Case 1 before treatment. The depletion of intracellular ATP would result in cellular disturbances. How rapid this can be is shown by the effect of the ingestion of $8 \mathrm{~g}$. fructose on the serum transaminases in Case 3. They rose to five times the fasting level 90 minutes after fructose administration (Table 1). This disturbance might apply not only to liver cells, but also to the cells of the brain and kidney where fructose is utilized, and could account for the renal manifestations such as aminoaciduria, and for the impairment of liver function. A similar suggestion has been put forward to account for some of the toxic manifestations of galactosaemia (Isselbacher, 1960) and receives some support from the observations of Penington and Prankerd (1958) who found that the ATP content of the red cells of a patient suffering from galactosaemia decreased when he was placed on a lactose diet.

Fructosaemia and Galactosaemia. The close similarity in the clinical and biochemical features of fructosaemia and galactosaemia led us to investigate the effects of galactose ingestion on the plasma levels of glucose, phosphorus and magnesium in galactosaemic patients. Two sibs aged 3 and 4 years, known to have galactosaemia, were investigated, and the results from one of them are shown in Fig. 7. The fall in blood glucose was not so striking as in the cases of fructosaemia, in neither instance being more than $25 \mathrm{mg}$. per $100 \mathrm{ml}$. The fall in plasma phosphorus and the rise in plasma magnesium were of the same order, however, as in the cases of fructosaemia. This further supports the suggestion that the depletion of intracellular ATP could be a cause of some of the toxic manifestations found in the two conditions.

In benign fructosuria, where the metabolic defect 


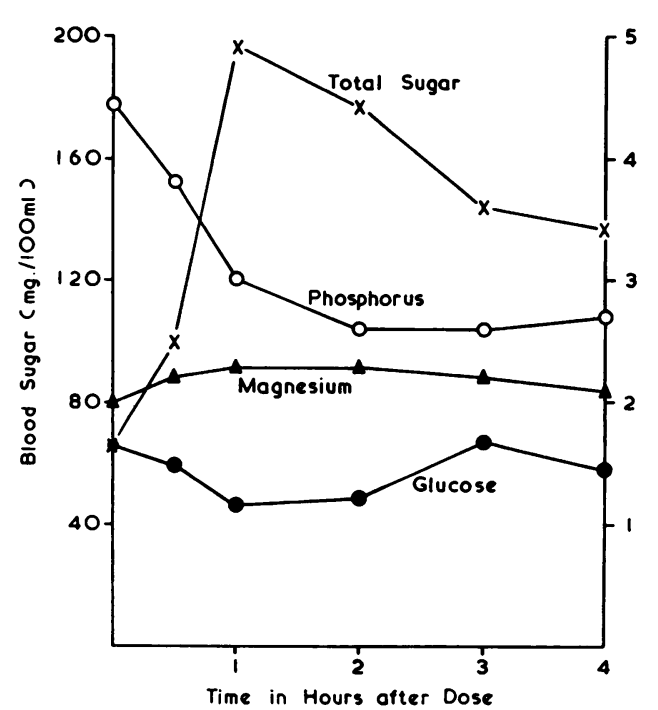

FIG. 7.-Case of galactosaemia. Changes in the levels of total blood sugar and glucose and plasma phosphorus and magnesium following ingestion of $20 \mathrm{~g}$. galactose $(1 \cdot 3 \mathrm{~g} . / \mathrm{kg}$.).

probably lies in the failure to convert fructose to fructose-1-phosphate, no alteration in plasma magnesium would be expected with fructose ingestion. Unfortunately, no such case was available for trial. However, impaired tolerance of fructose and galactose in cases of general liver dysfunction is also probably due to a deficiency in the initial stage of hexose phosphorylation, a stage which is similar in the metabolism of both sugars and which will be most stressed. A galactose tolerance test was, therefore, undertaken in an infant of 6 months (Y.G.) in whom the serum transaminases were greatly increased, and both fructose and galactose tolerance were markedly impaired. The total sugar, glucose, phosphorus and magnesium levels in the plasma were determined (Fig. 8). There was a marked rise in total blood sugar and a moderate rise in glucose. The plasma phosphorus fell only slightly, indicating that there was an impairment of initial phosphorylation. The level of plasma magnesium was unaltered throughout, indicating that the rise in the level found in fructosaemia and galactosaemia is associated with the block in the second stage in the metabolism of the sugar. It is interesting to note that despite the impaired carbohydrate tolerance tests, the levels of activities of both fructokinase and aldolase in the liver appeared normal.

Genetics. A review of the 16 cases described, including the three now reported, clearly confirms

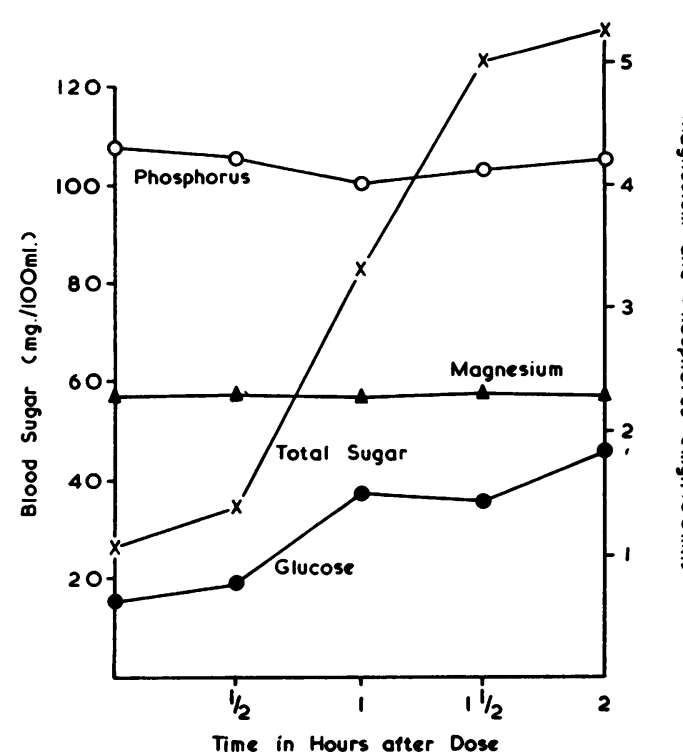

FIG. 8.-Case of impaired liver function. Changes in the levels of total blood sugar and glucose and plasma phosphorus and magnesium following ingestion of $7.5 \mathrm{~g}$. galactose $(1.9 \mathrm{~g} . / \mathrm{kg}$.$) .$

the suggestion that the condition is inherited as an autosomal recessive trait. Of the eight families involved, in only one instance was there a history of a parent being affected, whereas in four families, a sib has been found with the same condition. Consanguinity in parents was noted in the cases described by Froesch et al. (1957) and in one other family. The condition is not sex-linked as both females and males are affected, although with a preponderance of the former.

\section{Summary}

Three cases, two sibs and an infant of an unrelated family are described with fructosaemia, an inherited disorder of fructose metabolism.

A review of the 16 cases so far reported, including the present ones, shows that the younger age-group presents as failure to thrive, with vomiting and anorexia, hepatomegaly and hypoglycaemic attacks, following weaning from the breast. The older age-group is often symptomless, but with a marked aversion to sweetened foods. It is concluded that the defect is inherited as an autosomal recessive trait.

Measurements on a biopsy specimen of the liver from one of the three cases confirm that the underlying enzyme defect is an almost complete absence of liver aldolase activity to fructose-1-phosphate, with a markedly reduced activity to fructose-1:6diphosphate. 
The effect of the anomaly on carbohydrate metabolism is discussed. The severe hypoglycaemia found when fructose is ingested is not due to insulin response to high levels of fructose, but may result from the reduction in available intracellular phosphate by the accumulation of the blocked fructose-1phosphate. The ingestion of fructose results also in a decrease in the plasma phosphorus and an increase of plasma magnesium. It is postulated that both may be due to the consumption of ATP$\mathrm{Mg}$ complex to form fructose-1-phosphate, ADP and free magnesium. The depletion of ATP, it is suggested, may be responsible for some general cellular disturbances and toxic manifestations. Similar changes were found after oral galactose in two cases of galactosaemia, and the clinical and biochemical similarity and the differentiation between this condition and fructosaemia are discussed.

In view of the possibility of physical and mental retardation in untreated cases, the importance of early diagnosis is stressed.

We are indebted to Mr. Swain and Mr. Lister for the liver biopsies. The unfailing help and co-operation of the nursing staff and, in particular, Sister Barrett, are also gratefully acknowledged.

\section{REFERENCES}

Cusworth, D. C., Dent, C. E. and Flynn, F. V. (1955). The aminoaciduria in galactosaemia. Arch. Dis. Childh., 30, 150.

Dent, C. E. (1957). Clinical applications of aminoacid chromatography. Scand. J. clin. Lab. Invest., 10, Suppl. 31, 122.

Dormandy, T. L. and Porter, R. J. (1961). Familial fructose and galactose intolerance. Lancet, 1, 1189.

Dubois, R., Loeb, H., Ooms, H. A., Gillet, P., Bartman, A. and Champenois, A. (1961). Etude d'un cas d'hypoglycémie fonctionelle par intolérance au fructose. Helv. paediat. Acta, 16, 90 .
Froesch, E. R., Prader, A., Labhart, A., Stuber, H. W. and Wolf, H. P. (1957). Die hereditäre Fructoseintoleranz, einer bisher nicht bekannte kongenitale Stoffwechselstörung. Schweiz, med. Wschr., 87, 1168 . Wschr., Wolf, H. P. and Labhart, A. (1959). Die hereditäre Fructoseintoleranz. Helv. paediat. Acta, 14, 99.

Hers, H. G. (1957). Le Métabolisme du Fructose. Editions Arscia, Brussels.

- and Joassin, G. (1961). Anomalie de l'aldolase hépatique dans l'intolérance au fructose. Enzymol. biol. clin., 1, 4.

Isselbacher, K. J. (1960). Galactosemia. In The Metabolic Basis of Inherited Disease, ed. J. B. Stanbury, J. B. Wyngaarden and
D. S. Fredrickson, pp. 208-225. McGraw-Hill, New York.

Jeune, M., Planson, E., Cotte, J., Bonnefoy, S., Nivelon, J. L. and Skosowsky, J. (1961). L'Intolérance héréditaire au fructose: A propos d'un cas. Pédiatrie, 16, 605 .

Lasker, M. (1941). Essential fructosuria. Hum. Biol., 13, 51

Levin, B., Mackay, H. M. M., Neill, C. A., Oberholzer, V. G. and Whitehead, T. P. (1959). Weight gains, serum protein levels and health of breast-fed and artificially-fed infants, fullterm and premature. Spec. Rep. Ser. med. Res. Coun. (Lond.), No. 296. H.M.S.O., London.

Leuthardt, F. (1957). The place of fructose in intermediary metabolism. Colloq. Ges. physiol. Chem., 8, 1.

- Testa, E. and Wolf, H. P. (1953). Der enzymatische Abbau des Fructose-1-phosphats in der Leber. III. Mitteilung über den Stoffwechsel der Fructose in der Leber. Helv. chim. Acta, 36, 227.

Nikkilä, E. A., Somersalo, O., Pitkänen, E. and Perheentupa, J. (1962). Hereditary fructose intolerance, an inborn deficiency of liver aldolase complex. Metabolism 11, 727.

Peanasky, R. J. and Lardy, H. A. (1958). Bovine liver aldolase isolation, crystallisation and some general properties. J. biol. Chem., 233, 365 .

Penington, J. S. and Prankerd, T. A. J. (1958). Studies of erythrocyte phosphate ester metabolism in galactosaemia. Clin. Sci., 17,385 .

Sachs, B., Sternfeld, L. and Kraus, G. (1942). Essential fructosuria ; its pathophysiology. Amer. J. Dis. Child., 63, 252.

Sibley, J. A. and Lehninger, A. L. (1949). Determination of aldolase in animal tissues. J. biol. Chem., 177, 859.

Sidbury, J. B. (1957). The enzymatic lesions in galactosemia. J. clin. Invest., 36, 929. (1959). Zur Biochemie der hereditären Fructoseintoleranz. Helv. paediat. Acta, 14, 317.

Tung, T.-C., Ling, K. H., Byrne, W. L. and Lardy, H. A. (1954) Substrate specificity of muscle aldolase. Biochim. biophys. Acta (Amst.), 14, 488.

Van Geffel, R., Devriendt, A., Dustin, J.-P, Vis, $\mathbf{H}$ and Loeb, $\mathbf{H}$ (1959). La Maladie du Galactose, considérations Génétiques. Étude de l'amino-acidémie et de l'amino-acidurie. Arch. franc. Pédiat., 16, 158.

Wolf, H., Zschocke, D., Wedemeyer, F. W. and Hübner, W. (1959) Angeborene hereditäre Fructose-intoleranz. Klin. Wschr., 37, 693 . 